\title{
An Appropriated History: The Case of the Amsterdam Town Hall (1648-1667)
}

\author{
Pieter Vlaardingerbroek
}

Precedence is one of the key characteristics of mankind, now and also in the Early Modern Age. The importance of being first must never be underestimated when people are concerned. The same goes for cities, as is made clear by Konrad Ottenheym's article on Dutch town halls. Cities in Holland vied to be the oldest: priority in age determined the sequence of speech in the States of Holland. Dordrecht held the best papers, being the oldest, but Haarlem, Leiden, Delft and Alkmaar did their utmost to rewrite history in such a way, that they could claim to be the oldest. ${ }^{1}$ The impact of this discussion is visible when looking at the town halls or other public buildings. Parts of outdated town halls or court buildings were kept as a remembrance to the ancient history of the city.

In the seventeenth century, Amsterdam was by far the largest and most important city in Holland. It could, however, not compete in this game of being the oldest. It was a young city, founded by fishermen and farmers and first mentioned in the archives in 1275. There was nothing that could sustain the claim of being an old city. The medieval town hall that was used until ${ }_{1652}$ consisted of a redeveloped monastery with a tower and judicial court added around $1425^{-1450}$. In the seventeenth century it was in such a dilapidated state that the spire of the tower had to be taken down. It befitted in no way the new status of the city as one of the leading trade capitals of the world [Fig. 17.1]. This caused quite a problem for instance during the visit of Maria de Medici in 1638, when the vibrant city wanted to elevate itself to the level on which kings and queens acted. ${ }^{2}$ The minister and philosopher Caspar Barlaeus was made responsible for the reception of the queen. He wrote:

1 Schama S., The Embarrassment of Riches. An Interpretation of Dutch Culture in the Golden Age (London: 1991 [1987']) 75; Enenkel K.A.E. - Ottenheym K., Oudheid als ambitie. De zoektocht naar een passend verleden 1400-1700 (Nijmegen: 2017) 265-291.

2 Vlaardingerbroek P., Het paleis van de Republiek. Geschiedenis van het stadhuis van Amsterdam (Zwolle: 2011) 15-22. $^{-2}$

(C) PIETER VLAARDINGERBROEK, 2019 | DOI:10.1163/9789004378216_019

This is an open access chapter distributed under the terms of the prevailing CC-BY-NC-ND License at the time of publication. 
Mere Marie de Medicis arriva en cette ville le premier jour de ce mois. Elle fut recevu par l'auguste Senat \& par la Bourgeoisie avec toutes les marques d'honneur deues à sa qualité. Lorsqu'elle fut proche de cette ville, une compagnie de chevaliers qui se faisoient remarquer par leurs chevaux caparaçonnes en sortit pour aller à sa rencontre. Car elle n'alloit pas à un combat ni à la guerre, mais pour recevoir honorablement \& d'une maniere convenable une tres Auguste Epouse d'un grand Monarque, Mere de trois Rois, issue d'Empereurs par sa Mere, \& des Ducs de Toscane par son Pere. ${ }^{3}$

Queen Mother Maria de Medici arrived in this city on the first day of this month. She was received by the revered Senate and by the Burgers with all sorts of honors due to her quality. When she was near this city, a company of horsemen, distinguished by their caparisoned horses drove out to meet her. Because they did not go to battle, nor to war, but to receive honorably and in a manner befitting a very august Spouse of a grand Monarch, mother of three kings, offspring of emperors by her mother and of the Dukes of Toscany by her father.

The visit of Maria meant the informal recognition of the Dutch Republic and a tribute to its most important city, that regarded itself as virtually independent. No longer a rebel city, Amsterdam was accepted as an important partner in diplomatic and financial matters. By erecting ephemeral architecture and staging plays on the canals, Amsterdam created a suitable entourage for the visit. Luckily, the large hall of the Kloveniersdoelen, the gathering space of the local militia, had just been finished and could be used for the reception. But Amsterdam lacked an impressive town hall in which the Queen of France and the mother (-in-law) of four thrones could be received. ${ }^{4}$ In the official publication commemorating this visit Barlaeus stated that 'the antiquity and dilapidation give this building some dignity'. Amsterdam was lucky to have such a government, spending its money on the layout of the city instead of a new and luxurious town hall, according to Barlaeus.

3 Wicquefort Joachim de, Lettres de M. J. de Wicquefort avec les reponses de M. G. Barlée (Amsterdam, George Gallet: 1696) 72 (letter XxIv, Amsterdam 16 September 1638).

4 She was the mother of Louis XIII, King of France. Two of her daughters were married to the Kings of England and Spain, and one to the Duke of Savoye.

5 In Dutch: 'D'ouderdom en bouwvalligheid geven dit gebouw eenige achtbaerheid'; Barlaeus Caspar, Blyde Inkomst der allerdoorluchtighste Koninginne Maria de Medicis t'Amsterdam (Amsterdam, Johan and Cornelis Blaeu: 1639) 47 (Dutch translation of Medicea Hospes). 


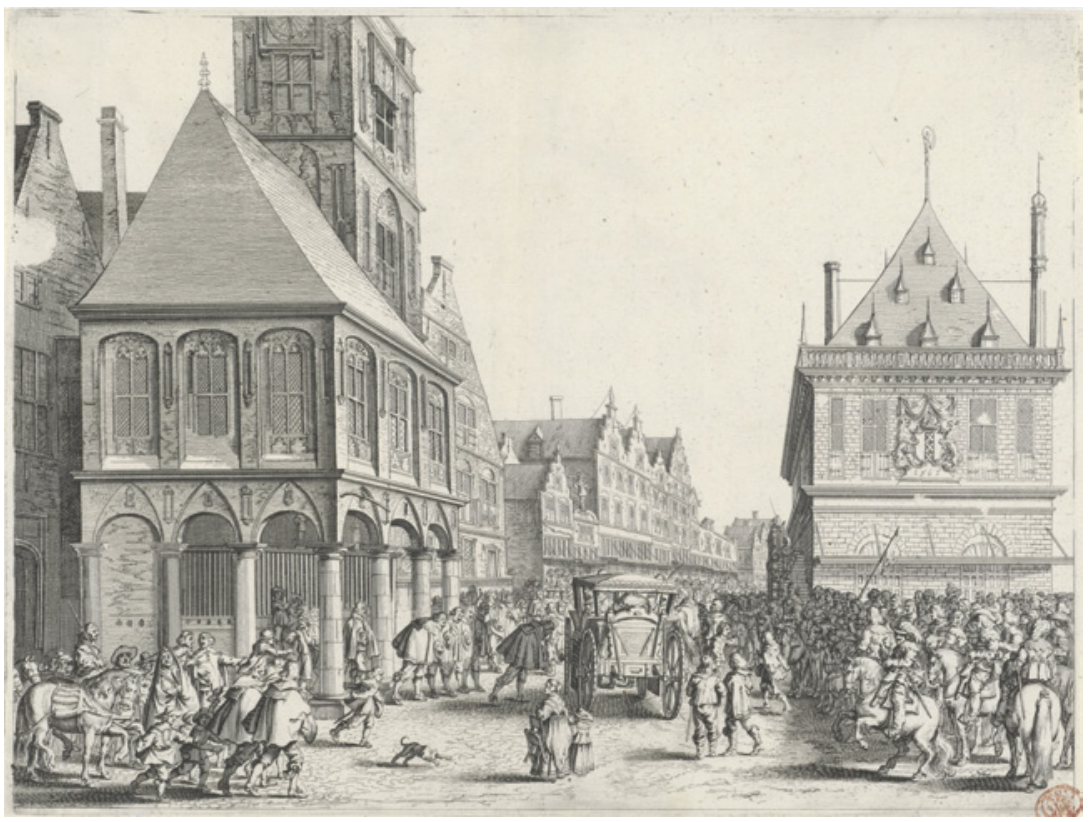

FIGURE 17.1 The medieval town hall of Amsterdam as it appeared during the visit of Maria de Medici in 1638. Salomon Jacobsz. Savery after Jan Martsz. de Jonge, taken from: Caspar Barlaeus, Blyde Inkomst der allerdoorluchtighste Koninginne Maria de Medicis t'Amsterdam (Amsterdam, Johan and Cornelis Blaeu: 1639). Etching, 28.5 × $38 \mathrm{~cm}$ IMAGE (C) RIJKSMUSEUM, AMSTERDAM

It can be argued whether the burgomasters of Amsterdam agreed. They regarded themselves equals to kings as is made clear by an (apocryphal?) incident during Maria de Medici's visit. Standing in front of the town hall, burgomaster Abraham Boom wanted to help her getting out of her carriage. Maria hesitated and asked 'Monsieur, vous êtes noble?', Boom answered 'Oui Madame, nous sommes les Rois du pays', upon which Maria took his hand to help her get out of the carriage. ${ }^{6}$ This idea of being kings can also be distilled from another passage from Barlaeus' book: 'Her Majesty was eager to see this city [Amsterdam], of which she had heard many outstanding and great things.' ${ }^{7}$ At the end of the visit, Maria addressed the burgomasters and said that she had heard many

6 Dudok van Heel S.A.C., “Op zoek naar Romulus en Remus. Zeventiende-eeuws onderzoek naar de oudste magistraten van Amsterdam”, Jaarboek Amstelodamum 87 (1995) 43-70. Another connection with nobility was made in 1655 , when the city acted as godfather of Carolus Emilius, son of the Elector of Brandenburg.

7 'Haere Majesteit was enkel belust om deze Stadt te bezien, van welcke haer eertijds veele treffelijcke en groote dingen ter ooren gekomen waeren'. Barlaeus, Blyde inkomst 6. 
things about the glory and excellence of the city, but that its fame was selling the city short: 'dat ze eertijds veel gehoort hadde van den luister en voortreffelijckheid dezer Stede, maer bevond dat de Faem die veel te kort dede' ('that beforehand she had learned a great deal about the magnificence and excellence of this city, but she experienced that its Fame was selling her short'). ${ }^{8}$ Barlaeus evidently alludes to the words of 1 Kings 10: 6-7 in which the queen of Sheba addresses Solomon after visiting Jerusalem:

And she said to the king, It was a true report that I heard in mine own land of thy acts and of thy wisdom. Howbeit I believed not the words, until I came, and mine eyes had seen it: and behold, the half was not told to me: thy wisdom and prosperity exceedeth the fame which I heard. ${ }^{9}$

Maria de Medici is put here in the admiring role of the Queen of Sheba, while Amsterdam is being compared to King Solomon, unparalleled in wisdom and wealth and fore fighter of peace.

Four months after the queen's visit, the burgomasters proposed to install a committee to investigate the possibilities of a new town hall. This committee worked from 1639 to 1648 to attain consensus on the size of the building lot. Political and financial circumstances varied and so did the size of the lot. The design was another point of discussion, leading to the question of the selfimage of the city. Instead of joining the argument of being the oldest - which Amsterdam could never win - the city changed the subject. Seeing itself more as an independent city state, Amsterdam looked for (historical) examples that went far beyond the local history of the province of Holland. Amsterdam wanted to draw historic parallels with other great cities that had been (or still were) the main capitals of the world. Until recently, mainly classical antiquity was seen as a source of influence for the preliminary and final designs of the Amsterdam town hall. For the preliminary designs this point of view seems to be correct as can be illustrated by the unexecuted designs for the Amsterdam town hall by the architect Philips Vingboons (1607-1678). He designed several variants, which were all influenced by buildings on the Capitoline Hill in Rome. One of his designs was printed in his book Afbeelsels der voornaemste

8 Idem 72.

9 I Kings 10: 6-7; used edition: The Bible. Authorized Version (Oxford: s.a.). 


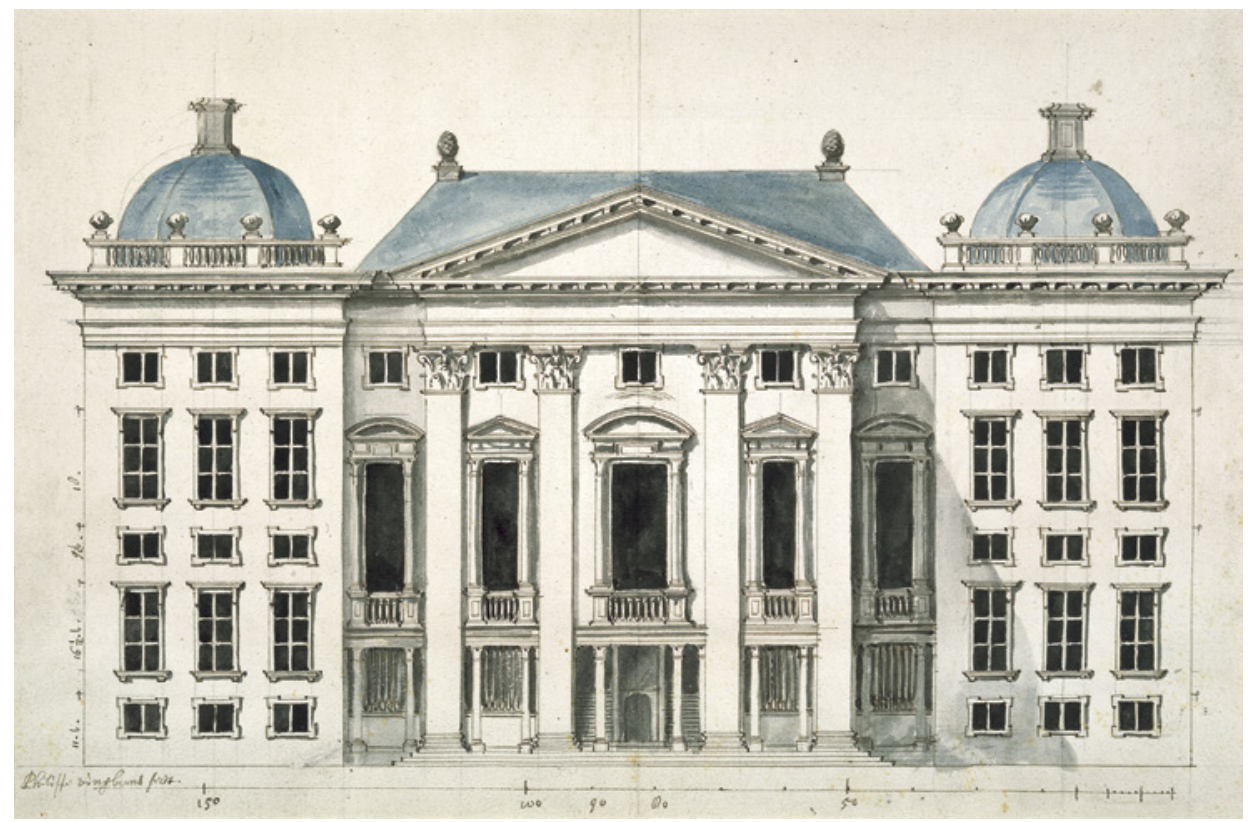

FIGURE 17.2 Philips Vingboons, (unexecuted) design for the Amsterdam town hall (1647). Drawing, $28.6 \times 40.9$ cm. British Library, Map Library, Collection Beudecker, Maps C.9.d.10, fol. 105

IMAGE (C) BRITISH LIBRARY

gebouwen uyt alle die Philips Vingboons geordineert heeft and clearly referred to the 'Palazzo dei Senatori', taking over the general shape and massing, as well as the staircase of the main façade. In the British Museum several drawings of another design are kept for which Michelangelo's Palazzo dei Conservatori served as example [Fig. 17.2]. Here we find the colossal Corinthian order combined with a smaller Ionian order. These elements can be seen as an architectural quote: Amsterdam presenting itself as the new Rome. ${ }^{10}$ These designs by Vingboons were not executed; possibly the connection with the Capitoline Hill was considered too vague to constitute a meaningful historical connection between the two cities. Ancient Rome played a part in the history of the Batavians, the people that were considered to be the Dutch forefathers during the time of the Roman Empire. The Batavians had been very important in the constitution of a Dutch identity, with many provinces claiming to be the

10 Ottenheym K., Philips Vingboons (1607-1678). Architect (Zutphen: 1989) 116-123; Vlaardingerbroek, Het Paleis 30-33. 
heartland of this Germanic tribe. ${ }^{11}$ From an architectural point of view, however, these Batavians had accomplished little to nothing. Their most famous gathering place did not even take place inside a building, but in a forest called Schakerbos. ${ }^{12}$ For architects there was little to refer to or to use as a source of inspiration when designing a new town hall. In this essay I will point out that antiquity in the seventeenth century comprised more than classical antiquity and that particularly the biblical antiquity played a large role in the final design of the Amsterdam town hall.

In 1648 Jacob van Campen (1596-1657) - who is famous for his role in introducing Palladian architecture in Holland - got the assignment to design the new Amsterdam town hall. The conditions for the new building had changed considerably since Vingboons had made his design. During the period 16401648 the measurements of the lot changed many times, from $150 \times 280$ feet in 1640 to $160 \times 200$ feet in 1645 to $165 \times 225$ feet in 1647 to $290 \times 225$ feet in 1648 [Fig. 17.3]. In the beginning, the building was planned deeper than wide, at the end it was wider than deep. The orientation of the lot had also changed. At first the new town hall had to fit in into the existing urban situation, but in the end the building lot became perfectly oriented with its façade on the Dam Square directed towards the east. The political situation had changed as well. With the Peace of Münster (part of the Peace of Westphalia) the Dutch Republic became an independent state in 1648 . To celebrate this joyous fact, Amsterdam wanted to dedicate the new town hall to Peace. Instead of placing the statue of Justice on top of the façade, a statue of Peace would crown the building [Fig. 17.4].13 Already in 1647 , before the actual decision was taken

11 Schama, Embarrassment 69-93; Langereis S., "Van botte boeren tot beschaafde burgers. Oudheidkundige beelden van de Bataven 1500-1800", in Swinkels L. (ed.), De Bataven. Verhalen van een verdwenen volk (Amsterdam - Nijmegen: 2004) 72-106; Schöffer I., "The Batavian Myth during the Sixteenth and Seventeenth Centuries", in Geurts P.A.M. Janssen A.E.M. (eds.), Geschiedschrijving in Nederland. Studies over de historiographie van de Nieuwe Tijd. Deel II: Geschiedsbeoefening (The Hague: 1981) 85-109.

12 The influence of the Batavians on painting is much bigger; see for instance the six enormous paintings of the Batavian history, which were painted for the galleries of the executed town hall; Zwaag M. van der - Cohen Tervaert R. (eds.), Opstand als opdracht (Amsterdam: 2011).

13 Fremantle K., The Baroque Town Hall of Amsterdam (Utrecht: 1959) 30-56; Goossens E.-J., "De Vredestempel. Het Amsterdamse stadspaleis uit 1648", in Dane J. (ed.), 1648. Vrede van Munster. Feit en verbeelding (Zwolle: 1998) 205-223. 


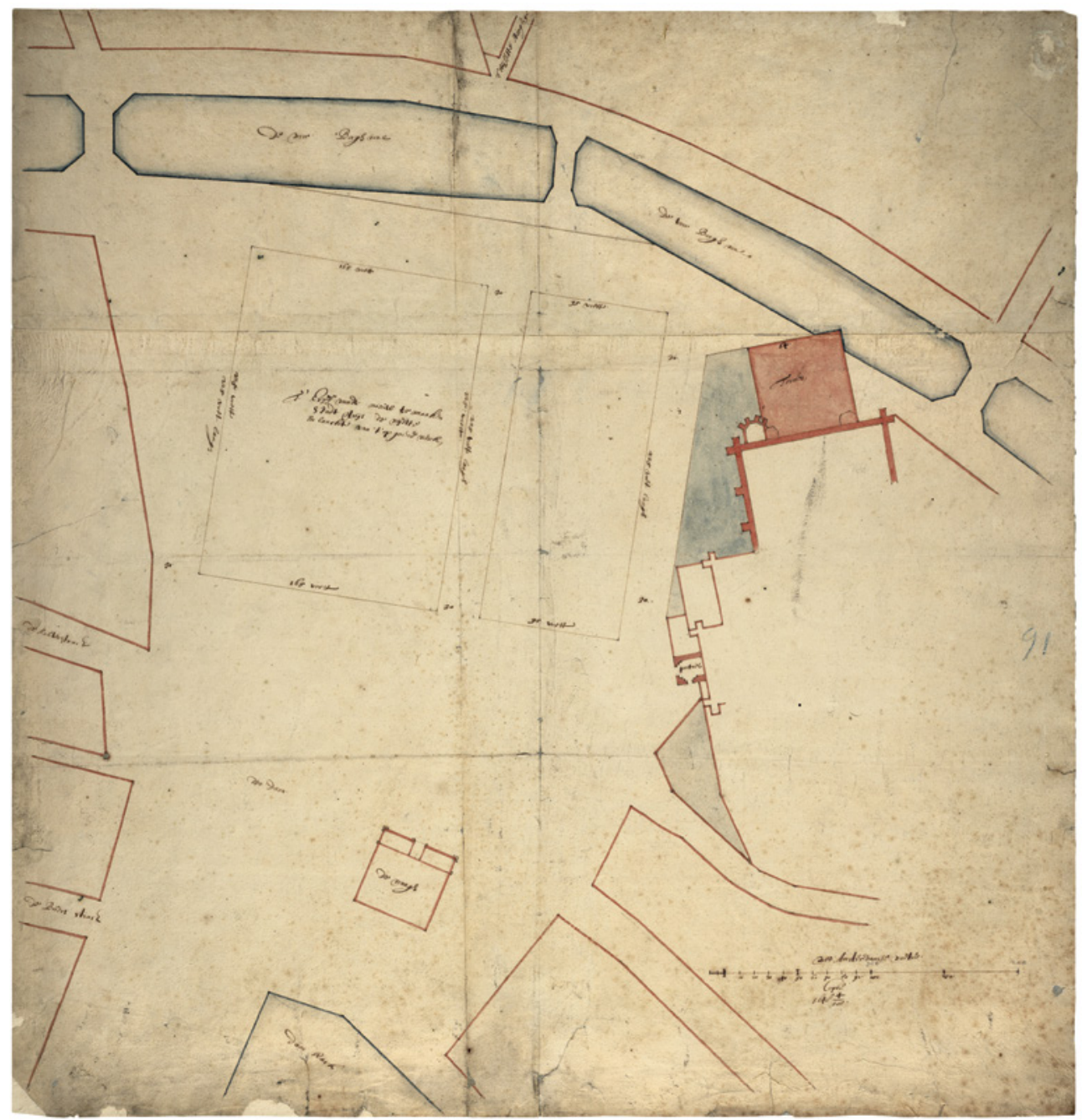

FIGURE 17.3 Cornelis Danckerts de Rij, The final building plot of the Amsterdam town hall (1648). Drawing. Stadsarchief Amsterdam

IMAGE @ STADSARCHIEF AMSTERDAM 


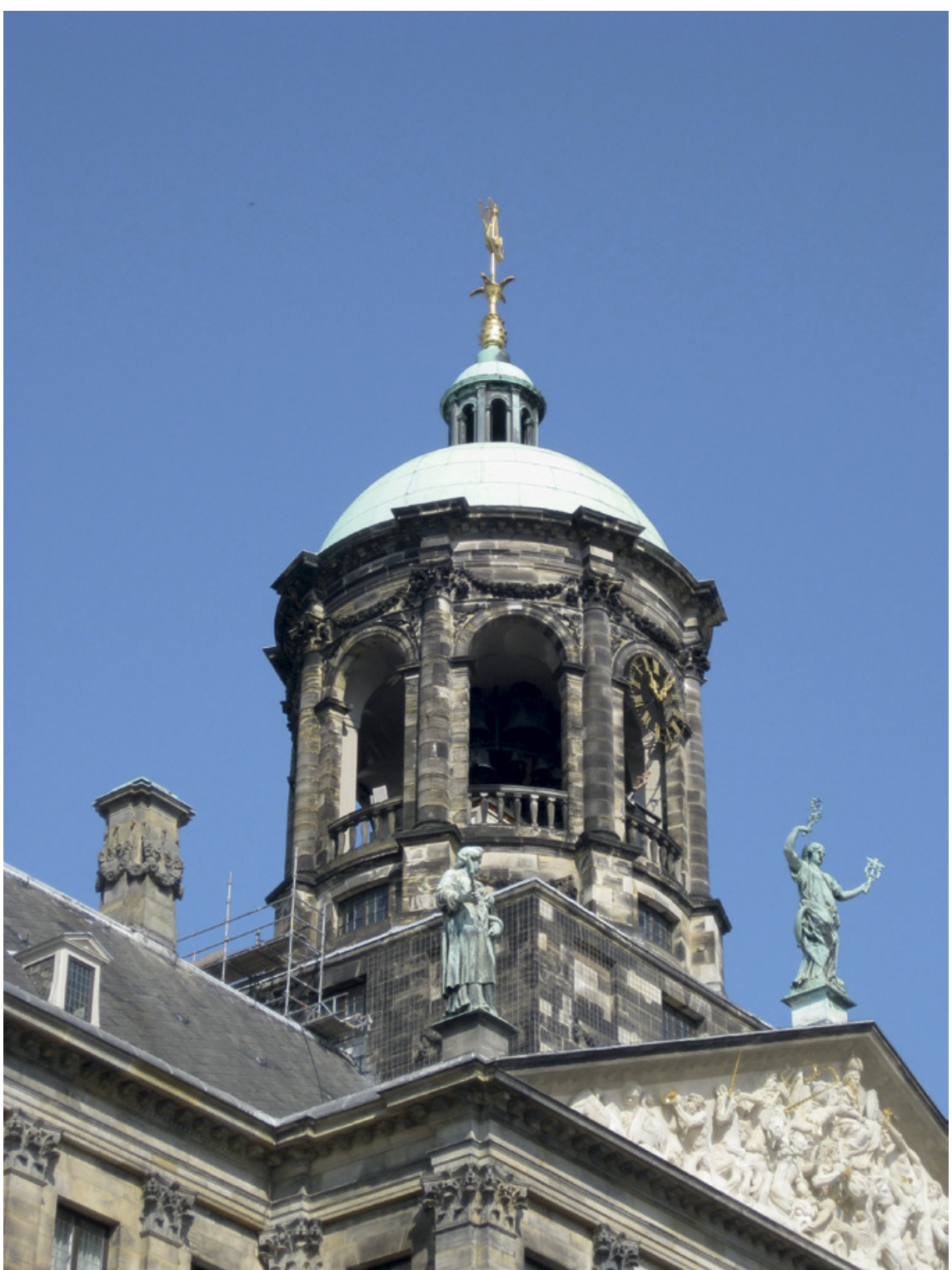

FIGURE 17.4 Artus Quellinus, The Allegory of Peace, on top of the town hall of Amsterdam (1665-1667). Copper IMAGE (C) AUTHOR 
to build the new town hall, the poet Joost van den Vondel connected the new building with Peace. ${ }^{14}$

On the 18 th of July 1648 the design by Van Campen was officially approved. ${ }^{15}$ The design consisted of a rectangular structure with two inner courtyards [Fig. 17.5]. Around these courtyards, Van Campen planned a system of galleries on the ground floor and on the first floor. These galleries were to give access to the offices. The galleries on the first floor were connected to the Great or Citizens' Hall ("Burgerzaal"), which formed the centre of the building. This enormous hall, 60 feet wide, 120 feet long and go feet high served as an internal square. The hall including the galleries measured 120 by 200 feet. In this new building, Van Campen had to allocate a great number of functions. In the seventeenth century Dutch town halls were more than just governmental buildings. They served for a very large part as a Courthouse and one could even argue that this function was the main function of a town hall. The façades of Dutch town halls are usually crowned by a sculpted allegory of Justice. In the executed building in Amsterdam, this is not the case but when looking at the ground plan, justice is evidently the main function of the building. ${ }^{16}$ The routing through the town hall was clearly defined by its public function as Courthouse. The main axe of the building housed the Criminal Court ("Vierschaar") on the ground floor, right in the middle at the Dam Square. On the first floor the main Courtroom was situated behind the Citizens' Hall, accessible through the largest gate in the building. Committees of the Municipality such as the City Council, and the burgomasters were located at the Dam side of the building, while the financial institutions such as treasurers and the trustees of orphans

\footnotetext{
14 Vlaardingerbroek, Het paleis 36. Vondel Joost van den, Leeuwendalers. Lantspel. Pax optima rerum (Amsterdam, Jacob Lescaille: 1647) 5:

'Maar wie zal de paiskroon spannen.

Onder ons doorluchte mannen,

Vredevaders, nimmer moe?

Zingze prijs en eere toe.

Noem nu elck een' lantbeschermer,

Waert een beelt van gout, of marmer,

By't gekroonde wapenkruis,

Midden voor ons nieuw stadthuis;

Dat gebouwt op die pylaren,

D'eeuwigheit, ontelbre jaren,

Kan verduren, zonder last,

Schoon de Nijt hiertegen barst'.

15 Vlaardingerbroek, Het paleis 36.

16 Vlaardingerbroek P., "Dutch Town Halls and the Setting of the Vierschaar", in Ottenheym K. - De Jonge K. - Chatenet M. (eds.), Public Buildings in Early Modern Europe (Turnhout: 2010) 105-118.
} 


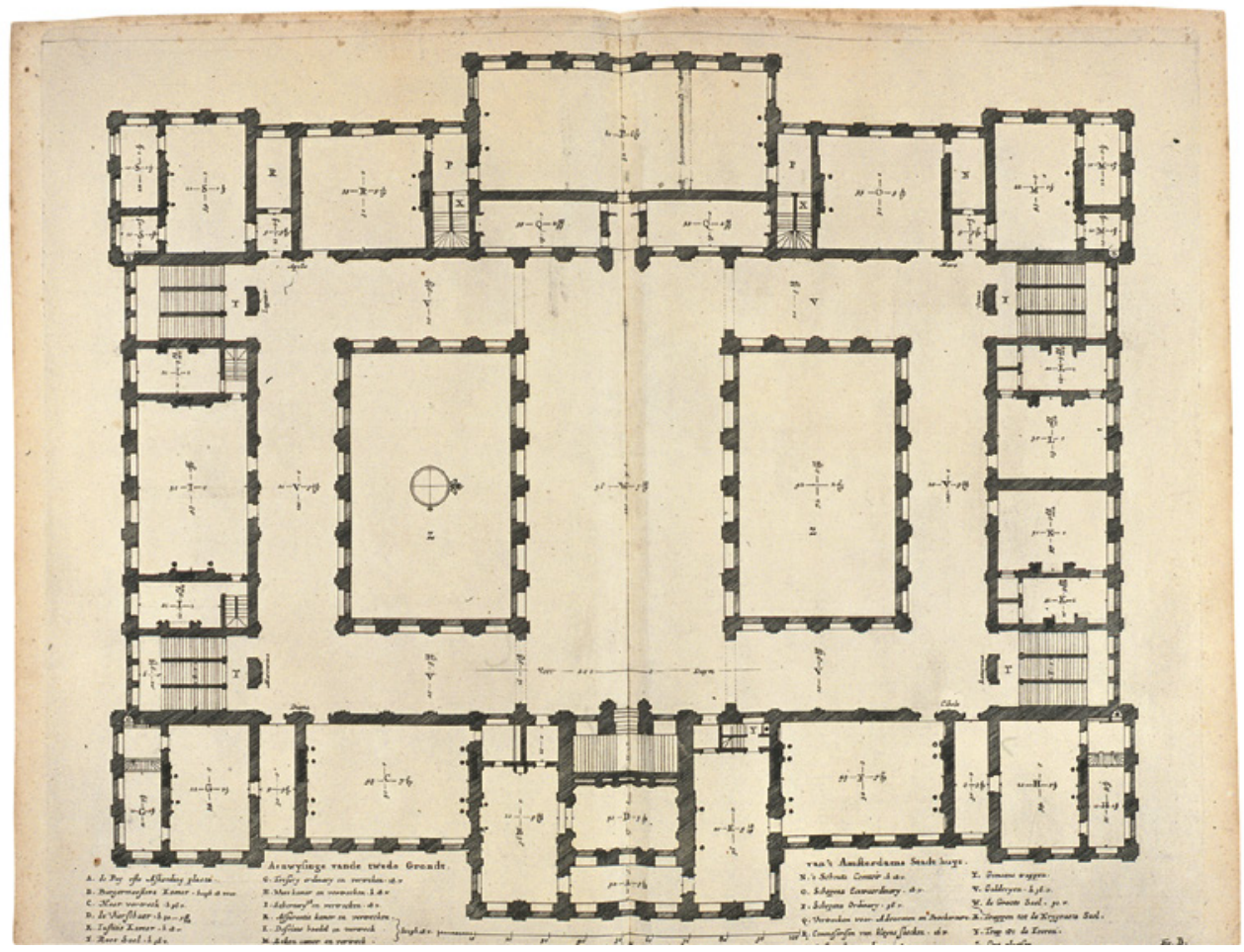

FIGURE 17.5 Jacob van Campen (architect), First or main floor of the Amsterdam town hall as depicted in Afbeelding van 't Stadt Huys van Amsterdam (Amsterdam, Dancker Danckerts: 1661) Print B IMAGE (C) UTRECHT UNIVERSITY LIBRARY

were situated in the corners, which made them less easy to find and less accessible to the public. The Exchange Bank of Amsterdam and the prisons were allocated in the ground floor. The exterior of the building was completely made out of perfectly hewn sandstone, which was quite exceptional in the Dutch Republic, where hardly any natural stone was excavated. The present façades are built up with an austere basement, followed by a Composite and a Corinthian order [Fig. 17.6]. The interior of the Citizens' Hall has two superimposed Corinthian orders [Fig. 17.7]. Originally, Van Campen planned the exterior to have two superimposed Corinthian orders as well, as is visible on one of the few remaining drawings from the construction period [Fig. 17.8]. This would have made the building even more classical than it is now, as the outside would have reflected the inside. ${ }^{17}$ 


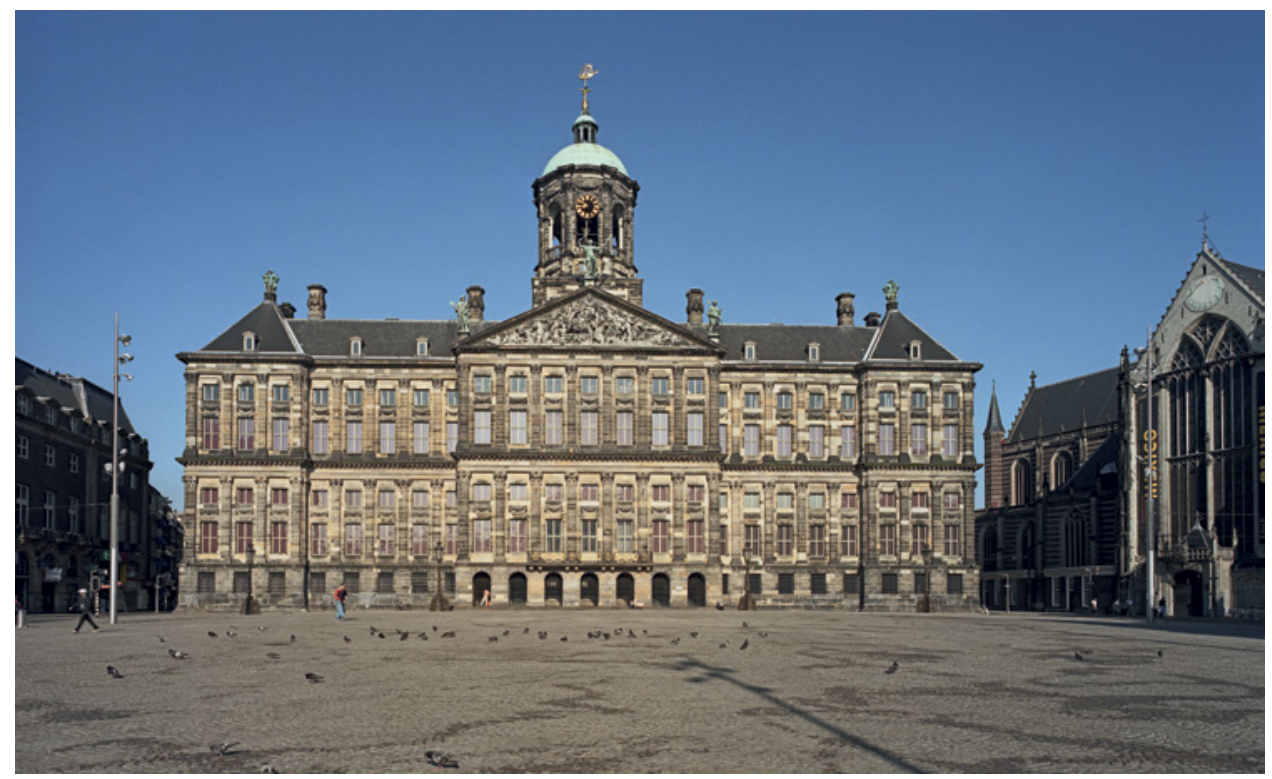

FIGURE 17.6 Jacob van Campen (architect), The exterior of the Amsterdam town hall (1648-1667). See also Fig. 16.8

IMAGE (C) RIJKSVASTGOEDBEDRIJF, WIM RUIGROK

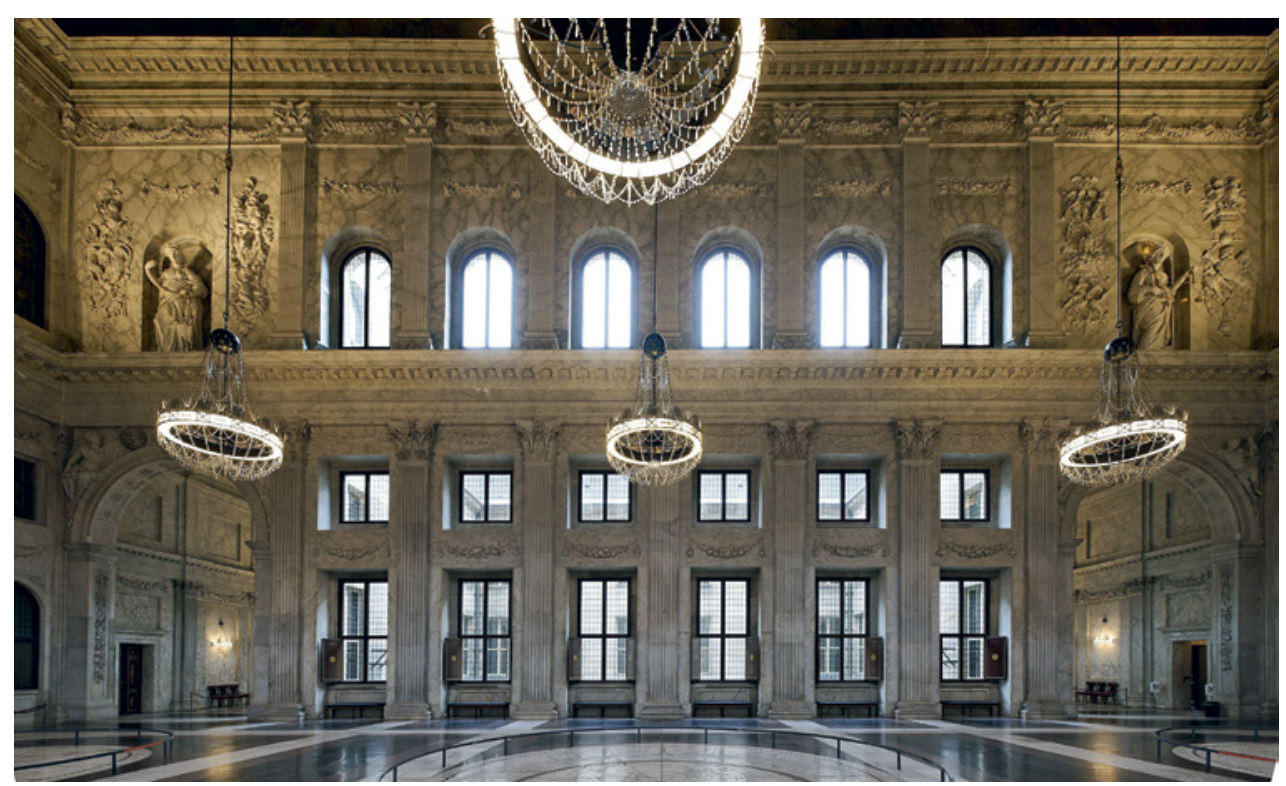

FIGURE 17.7 The interior of the Great of Citizens' Hall ("Burgerzaal") of the Amsterdam town hall, (1648-1667) IMAGE @ RIJKSDIENST VOOR HET CULTUREEL ERFGOED, CHRIS BOOMS 


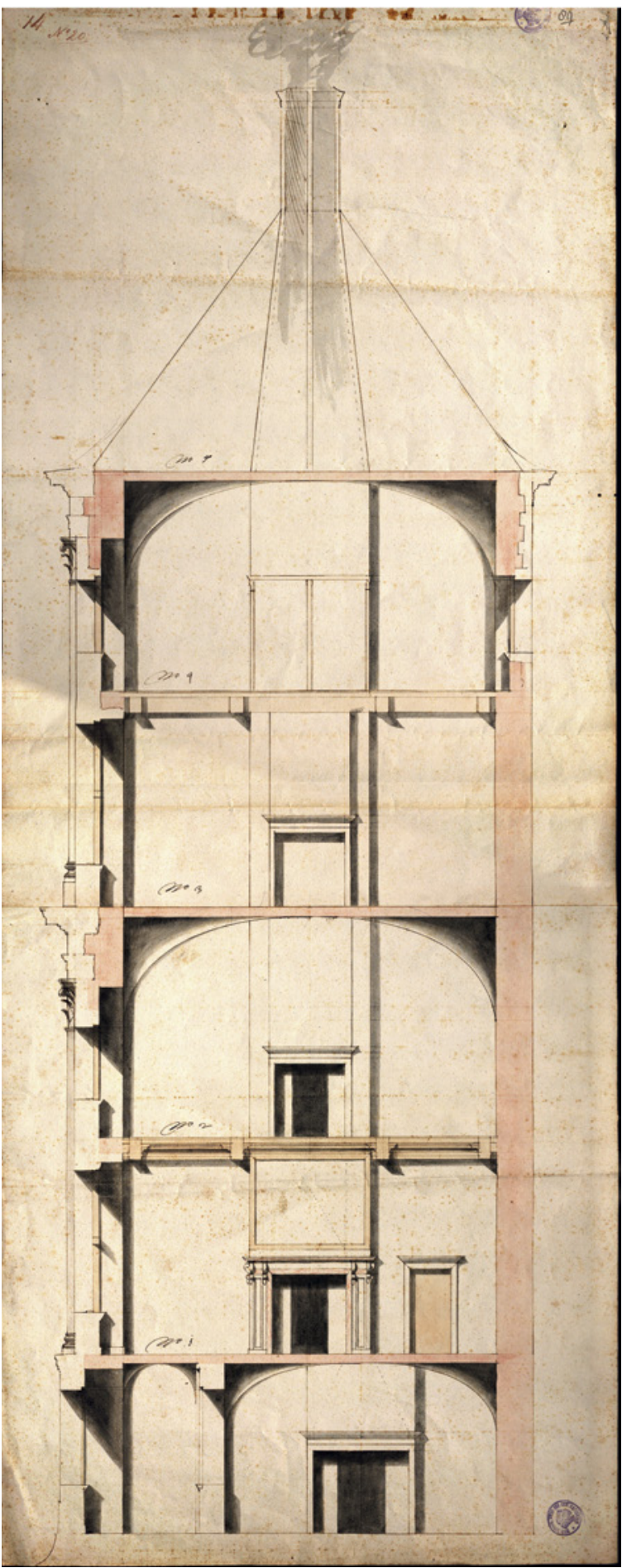

FIGURE 17.8

Unknown draughtsman, Section of the north wing of the Amsterdam town hall, showing a double Corinthian order.

Drawing, $140.1 \times 40.1 \mathrm{~cm}$. Stadsarchief Amsterdam IMAGE (C) STADSARCHIEF AMSTERDAM 
Van Campen found his source of inspiration by looking at history in another way than Vingboons did. Instead of the supposed 'real' history of Holland, inspiration could also be found in another way of historic thinking. The European Protestants and the Dutch in particular had a special bond with the Old Testament. They saw many parallels between themselves and the people of Israel, God's chosen people. The stories of the Catholic Saints were traded in for the stories of the Old Testament. The reading from Scripture and the sermon constituted the main elements of a protestant church service, as well as psalm singing in which Jerusalem and the Temple played a prominent role. Most Protestants had Bibles at home and reading them was made attractive by adding large-scale prints depicting the Ark of Noah, the Temple, Solomon's Palace or plans of Jerusalem. ${ }^{18}$ François Vatable's reconstructions of these structures were printed in Henry Estienne's French translation of the Bible, which was again translated in Dutch and known as the Deux-Aes Bible. ${ }^{19}$ This led to an increase in knowledge of the Bible and a growing identification with God's chosen people. Parallels were drawn between Dutch history and the history of Israel. 'In practice this meant that the Calvinist sense of their own dwelling in the contemporary world was saturated with scriptural allusion, analogy and example..20 This eventually led to the national consciousness of being 'Dutch Israel'. ${ }^{21}$

God's history with his chosen people of Israel was a very important part of the Protestant way of believing. It demonstrated the will of God and his powerful interventions the get his chosen people back on the right track. This history of God and his chosen people was a source of many analogies for the Dutch. Just as the people of Israel were saved from the cruelties of Egypt, the Dutch were liberated from the Spanish. They saw themselves as the newly chosen people. Only with God's special help a country like the Netherlands could have acquired this enormous wealth and power. Already in 1569, a print appeared in which William the Silent was compared to Joshua, the military leader who led

18 Poortman W., Bijbel en prent (The Hague: 1983); Coelen P.J.H. van der, De Schrift verbeeld. Oudtestamentische prenten uit renaissance en barok (Nijmegen: 1998) 190-201.

19 Linden C.J.R. van der, "De symboliek van de Nieuwe Kerk van Jacob van Campen te Haarlem", Oud Holland 104 (1990) 1-31.

$20 \quad$ Schama, Embarrassment 95.

21 Groenhuis G., "Calvinism and National Consciousness: the Dutch Republic as the New Israel", in Duke A.C. - Tamse C.A. (eds.), Britain and the Netherlands. Church and State since the Reformation (The Hague: 1981) 188-133; Huisman C., Neerlands Israël. Het natiebesef der traditioneel-gereformeerden in de achttiende eeuw (Dordrecht: 1983). 
the people of Israel into Canaan. ${ }^{22}$ In 1594 prince Maurits received a glorious entree in Amsterdam after he had won Groningen from the Spaniards, portraying him as David triumphing over Goliath. ${ }^{23}$

This religious aspect of Dutch history had a topographical and architectural counterpart. ${ }^{24}$ There was a demand for books with geographical knowledge about the places indicated in the Bible, both topographical and architectural. See for instance the many editions of Theatrum Terrae Sanctae et Biblicarum Historiarum, in which Christiaan van Adrichem described a multitude of holy places. ${ }^{25}$ Of course, the Temple of Solomon was one of the most important buildings. Already in 1630 Constantijn l'Empereur van Opwijck (1591-1648) published a Latin translation of Middot, a tract of the Mishnah that discusses the measurements of the Temple. ${ }^{26}$ This interest in Biblical topography was however bigger than just the Temple. Protestant theologians studied all kinds of buildings, mostly in cooperation with Jewish scholars. Some Protestants like Adam Boreel (1603-1665) believed that the Messiah would return when the Jews also accepted Him as their Savior. He asked the Sephardic scholar Jacob Jehuda Leon (1602-1675) to study buildings in the Holy Land in order to have a possibility to an interreligious discussion and an opportunity to convince Jews to convert to Christianity. Leon, who lived in Middelburg and Amsterdam respectively, made a model of the Temple around 1640. But he also reconstructed other buildings and architectural elements, such as the Tabernacle, the Ark

22 Horst D.R., De Opstand in zwart-wit. Propagandaprenten uit de Nederlandse Opstand (1566-1584) (Zutphen: 2003) 109-111, 295-300.

23 Snoep D.P., Praal en propaganda. Triumfalia in de Noordelijke Nederlanden in de $16^{\text {de }}$ en $17^{\text {de }}$ eeuw (Alphen a.d. Rijn: 1975) 32.

24 For the most recent literature about the influence of the Temple on Dutch architecture, see: Goudeau J., "Ezekiel for Solomon. The Temple of Jerusalem in Seventeenth-century Leiden and the Case of Cocceius", in Goudeau J. - Verhoeven M. - Weijers W. (eds.), The Imagined and Real Jerusalem in Art and Architecture (Leiden - Boston: 2014) 88-113; Linden, "De symboliek" 1-31; Steenmeijer G., Tot cieraet ende aensien deser Stede. Arent van's-Gravesande (ca. 1610-1662), architect en ingenieur (Leiden: 2005); Vlaardingerbroek, Het Paleis 69-72; idem, "The Snoge: A Jewish building in a Dutch architectural style", in idem (ed.), The Portuguese Synagogue in Amsterdam (Zwolle: 2013) 55-72, esp. 64-72.

25 See for instance the many editions of Adrichomius Christianus, Theatrum Terrae Sanctae et Biblicarum Historiarum cum tabulis geographicis aere expressis (Cologne, Arnold Mylius: 1593).

26 Steenmeijer, Tot cieraet 184 . 
and its Cherubim and Solomon's Palace. ${ }^{27}$ He tried to reconstruct these structures by following the biblical texts closely. These models were on display at his house in Amsterdam and shown on fairs. In 1642 he published his findings on the Temple in his Afbeeldinghe van den Tempel Salomonis, which was translated and reprinted seven times. The print of the Temple includes also Solomon's Palace, which was situated next to the Temple. The combination of the main temple with a royal palace is a common one during history. Worldly power is legitimized by divine power; the king is seen as a representative of God. ${ }^{28}$ This idea of combining Solomon's Palace and Temple remained influential during the seventeenth century. Olfert Dapper in his Naukeurige beschrijving van gantsch Syrië en Palestijn of Heilige Lant (Precise Description of whole Syria and Palestine or Holy Land) depicted almost an identical view on both buildings as Leon did [Fig. 17.9]. ${ }^{29}$ The palace was visualized as a rectangular structure with three classical orders, having a central risalite and tower-like structures at its corners. It comprised the House of the King, the House of the Queen, as well as the House of the Forest of the Lebanon, Solomon's Courtroom.

This interest in biblical architecture was common in the whole of Europe, both in Protestant and Catholic circles. ${ }^{30}$ Two methods of research coexisted, especially concerning the Temple. Some had an antiquarian approach based on biblical texts, while others had a more spiritual view on the Temple, trying to recreate architecture in most perfect form as a true reflection of divine wisdom. In the case of the spiritual approach, the Temple was seen as a theological reconstruction in which the restored Temple was a spiritual image, representing the resurrection of Christ. ${ }^{31}$ This wisdom was revealed in the proportions of the Temple, which God Himself had given to David and Solomon. The Temple was a mathematical expression of Gods "idea" behind His creation, an example

27 Leon Jaacob Jehuda, Tratado de la Arca del Testamento (Amsterdam, Nicolas Ravesteyn: 5413 [i.e. 1653]); Leon Jaacob Jehuda, Retrato del Tabernaculo de Moseh (Amsterdam, Gillis Joosten: 5414 [i.e. 1654]); Leon Jaacob Jehuda, Tratado de los Cherubim (Amsterdam, Nicolas Ravesteyn: 5414 [i.e. 1654]).

28 Offenberg A.K., "Jacob Jehudah Leon en zijn tempelmodel: een joods-christelijk project", De Zeventiende Eeuw 9 (1993) 35-50; Offenberg A.K., "Jacob Jehuda Leon (1602-1675) and his Model of the Temple", in Berg J. van den - Wall E.G.E. van der (eds.), Jewish-Christian Relations in the Seventeenth Century (Dordrecht - Boston - London: 2004) 95-115.

29 Dapper Olfert, Naukeurige beschrijving van gantsch Syrië en Palestijn of Heilige Lant (Amsterdam, Jacob van Meurs: 1677) print between pages 446-447.

30 Herrmann W., "Unknown Designs for the 'Temple of Jerusalem' by Claude Perrault", in Fraser D. - Hibbard H. - Lewine M.J. (eds.), Essays in the History of Architecture presented to Rudolf Wittkower (London: 1967) 143-158.

31 Morrison T., Juan Bautista Villalpando's Ezechielem Explanationes. A Sixteenth-Century Architectural Text (Lewiston - Queenston - Lampeter: 2009) 28. 


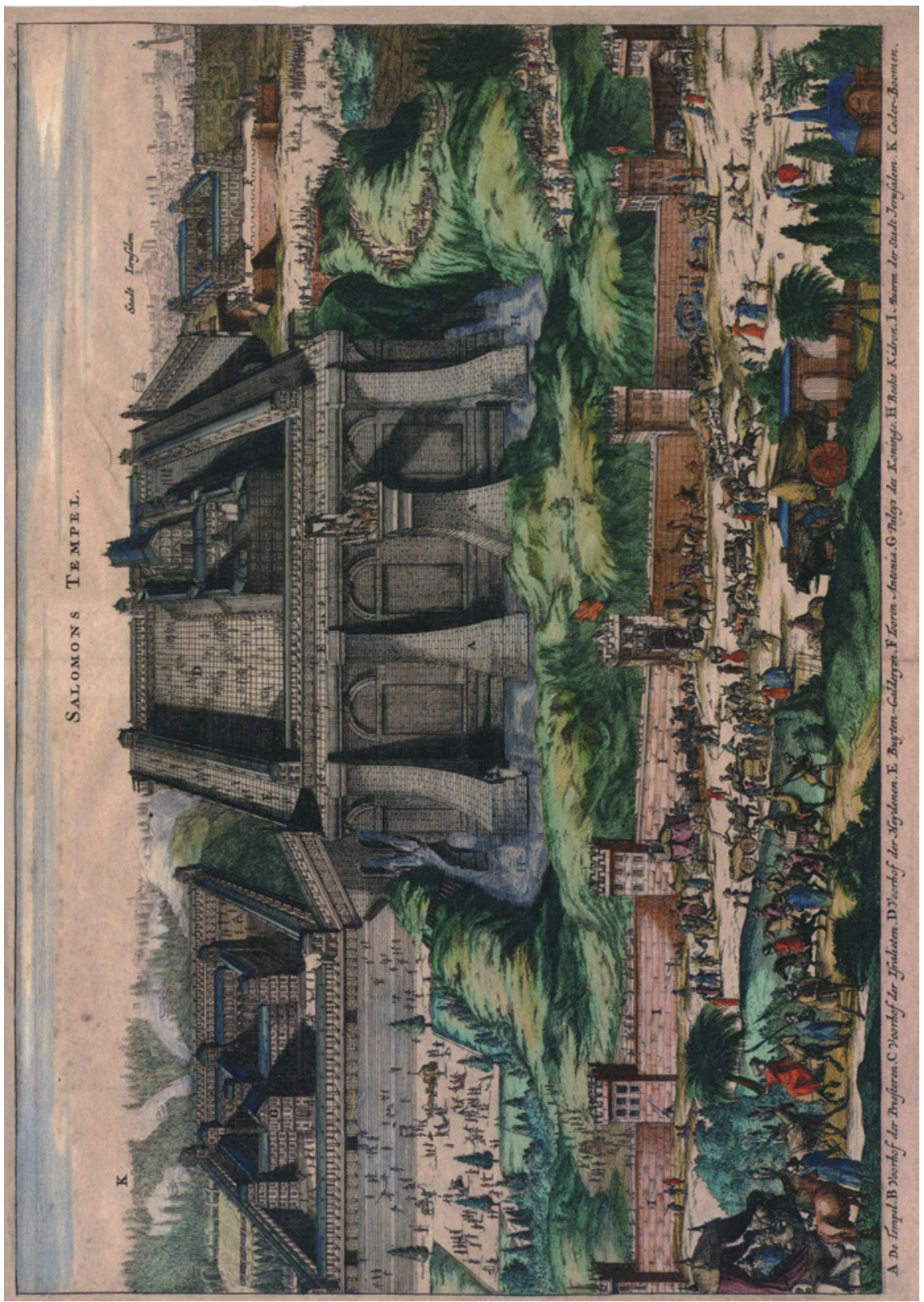

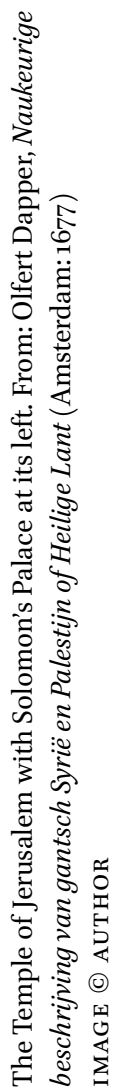

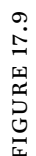


of a structure in the micro cosmos that mirrored the proportions existing in the macro cosmos. A fine example of this direction can be found in the books by Juan Bautista Villalpando, In Ezechielem explanationes et apparatus Urbis ac Templi Hiersolymitani, published in Rome in 1596-1605. Villalpando declared Ezekiel's vision of the Temple to be a description of Solomon's Temple, despite all differences between the biblical texts in Ezekiel and the book of Kings. According to Villalpando, classical architecture derived from the architecture of the Temple; the Solomonic order was the origin of all other classical orders (Doric, Ionic and Corinthian). The Solomonic capitals were made up out of lilies and resembled the Corinthian order. In other words, the Temple was the origin of classical architecture, which was later taken over by the Greeks and the Romans. According to Villalpando, Vitruvius' book De Architectura libri decem was merely an interpretation of biblical architecture. Villalpando inserted large-scale prints of the Temple to clarify his architectural vision of the Temple. The Temple had a square ground plan, consisting of seven square courtyards and one rectangular courtyard on which the actual Temple with the Holy of Holies stood. The façades were covered with pilasters, while the Temple and the Temple Mount also had curving buttresses. Villalpando is however more than just the reconstruction of the Temple. The second of the three volumes (1604) gives an elaborate reconstruction of Jerusalem and other biblical architecture as well. Especially Solomon's Palace got a great deal of attention.

\section{The Influence of Biblical Architecture on Dutch Architecture}

Villalpando had an enormous effect on Dutch architectural theory. The influential architecture theoretician Nicolaus Goldmann was one of his followers. Following the ideas of Villalpando, architecture would become some kind of micro cosmos, having a direct mathematical relation to all things created by God. A perfectly Platonic idea, in which human architecture resembles divine architecture (creation). ${ }^{32} \mathrm{~A}$ similar attitude can be found in Wilhelmus Goeree's treatise d'Algemeene Bouwkunde in which he considered Solomon's Temple to be the origin of architecture. ${ }^{33}$ Villalpando must have been widely available in Holland, although little archival references can corroborate this idea. Several times the book is mentioned in archival sources. In 1658 the Amsterdam

32 Goudeau J., Nicolaus Goldmann (1611-1665) en de wiskundige wetenschap (Groningen: 2005) 327-342.

33 Goeree Wilhelmus, D'algemeene bouwkunde, volgens d'antyke en hedendaagse manier (Amsterdam, Wilhelmus Goeree: 1681) 9. 
burgomaster Joan Huydecoper (1625-1704) received his copy of Villalpando's book. ${ }^{34}$ We can surmise that Jacob van Campen studied Villalpando together with Constantijn Huygens (1596-1687), secretary to stadtholder Frederik Hendrik. Huygens asked his friend Joachim de Wicquefort in 1634 to lend him his copy, which he received in 1636 . Recently, Huygens own copy was discovered in the University Library of Nijmegen, signed 'Constanter 1637' ${ }^{35}$

Van Campen hasn't written down his thoughts on architecture. There is however a letter of the poet and botanist Johan Brosterhuijsen (1596-1650) addressed to Constantijn Huygens, in which he refers to an essay about the origin of architecture, being written by Van Campen. ${ }^{36}$ It had to appear in a book, combined with a translation of Vitruvius' book De Architectura Libri Decem, Henry Wotton's Elements of Architecture, as well as some passages from Andrea Palladio's I Quattro Libri dell'Architettura (1570), concerning temples and public buildings such as the Basilica. This treatise, which unfortunately was never realised, would have given the reader an overview on architecture in general. Contemporary literature was added to Vitruvius in order to give more practical information about architecture in general. Wotton's book would have served as a more accessible introduction to the classical book of Vitruvius, which contained some passages, which were rather difficult to understand. Of course, Vitruvius would function as core-text, giving a complete overview on architecture. Some paragraphs from Palladio's very influential treatise were added on Van Campen's advice; these texts were about temples and public buildings such as the classical Basilica, which had evolved since Vitruvian times into a modern Basilica. Van Campen's essay would probably have been the general introduction to the book. The origin of architecture seems a rather vague term, but it is not unlikely that it had something to do with the divine origin of architecture and the Temple of Jerusalem as an expression of this idea. For architects a very attractive theory of course, because if they understood the divine creation, they themselves would be able to make architecture resembling divine perfection. Van Campen designed three churches in which the influence

34 Het Utrechts Archief, Archief Huydecoper (67), inv. no. 54 (1658), letter of Huydecoper to Charles Angot, February 21 1658. In his book in 1659 Huydecoper mentions: 'Usque ad Caput XVII Esechielis' (Het Utrechts Archief, Archief Huydecoper [67], inv. no. 55, Libri Lecti).

35 Goudeau J., Denken in steen, bouwen op papier. Een kleine geschiedenis van het architectuurboek (Nijmegen: 2016) 75 .

36 Leiden University, Library, special collections, inv. no. 37 (41): Johan van Brosterhuijsen to Constantijn Huygens, Amersfoort February 6 1642. See also Seters W.H. van, "Prof. Johannes Brosterhuysen (1596-1650). Stichter en opziener van het Medicinale Hof te Breda", Jaarboek de Oranjeboom 6 (1953) 106-151. 
of Villalpando's reconstruction of the Temple can be traced. ${ }^{37}$ In the case of the Amsterdam town hall, Solomon's Palace seems to be a more likely example.

\section{Source of Inspiration for the Amsterdam Town Hall}

Of course the Amsterdam burgomasters wanted to be equal to kings, but the fact remains that they were not. What they needed was a town hall with space for courtrooms, and a building that visualized the highest right the city had, which was the right to decide over life and death. Instead of looking at the Temple of Solomon, Van Campen used Solomon's Palace as an example. From a functional point of view, this choice was quite defendable. Solomon's Palace mainly functioned as a Courtroom, but it was also the seat of the government, an armoury, a treasure house and a prison. This set of functions fitted exactly to the situation in Amsterdam. Again, Villalpando proves to be a very valuable source. Unfortunately, Villalpando did not produce a detailed visual reconstruction of Solomon's Palace. It was visualized on a rather small scale on the map of Jerusalem [Fig. 17.10]. He made up for this by giving an elaborate description of the building, based on several texts in the Bible and especially on 1 Kings 7:1-12. He starts his description with the words of Flavius Josephus, who referred to the visit of the Queen of Sheba:

But she remained overwhelmed before the wisdom of the King, realizing that it was much greater than she had heard; there was cause for her to admire all the magnificence and elegance of the palace, the splendid order of the buildings, since in everything it shone with deep ingenuity. But above all, what astonished her most was the small palace that was

37 Ottenheym K., "Architectuur", in Huisken J. - Ottenheym K. - Schwartz G. (eds.), Jacob van Campen. Het klassieke ideaal in de Gouden Eeuw (Amsterdam: 1995) 155-199. In his churches in Renswoude, Hoge Zwaluwe and Haarlem (New Church) Van Campen copied the outward curving buttresses that were present in the Temple itself and the Temple Mount on which the actual Temple stood. This element was used in order to create a truly divine inspired architecture. Similar ideas can be found in the work of other leading architects in the seventeenth century: Salomon de Bray (1597-1664), Arent van 's-Gravesande (16101662), Pieter Post (1608-1669), Daniel Stalpaert (1615-1676), Adriaen Dortsman (16351682) and Elias Bouman (1635-1686). In their treatises or in their designs of churches and synagogues references to the Temple of Jerusalem are being made. Vlaardingerbroek, "The Snoge" 68-72; Kravtsov S.R., "Juan Bautista Villalpando and Sacred Architecture in the Seventeenth Century", Journal of the Society of Architectural Historians 64 (2005) 312-339. 


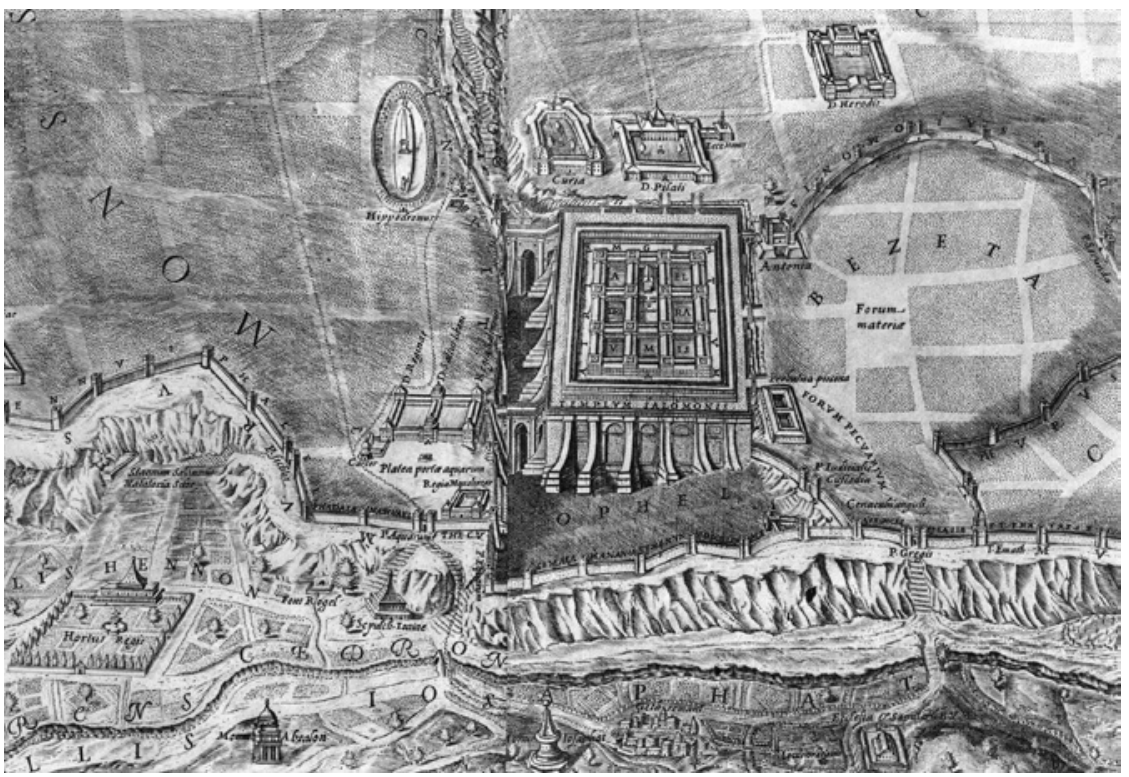

FIGURE 17.10A The Temple and the Palace of King Solomon in Jeruzalem. Detail of the map of Jerusalem from Juan Bautista Villalpando, In Ezechielem Explanationes et Apparatus Urbis ac Templi Hiersolymitani (Rome: 1596-1605), vol. II IMAGE (C) UNIVERSITY OF AMSTERDAM, LIBRARY

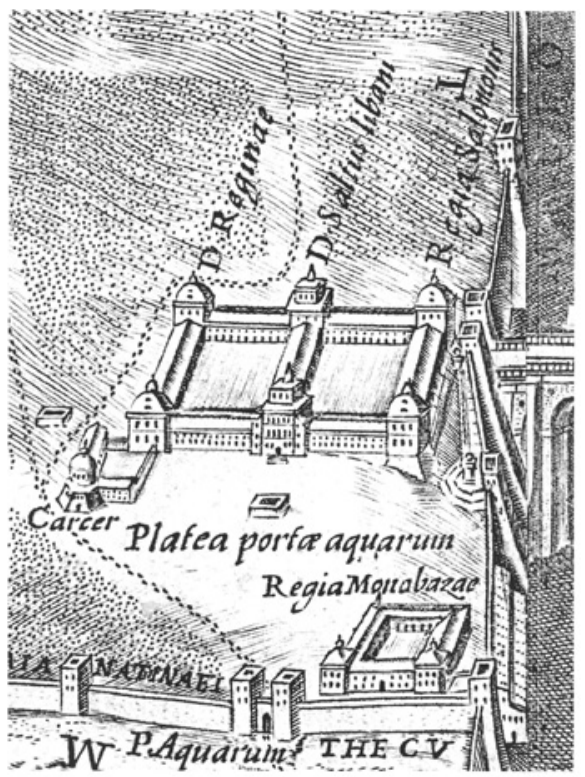

FIGURE 17.10B

The Palace of Solomon. Detail of Fig. 17.10a 
called the 'House of the Forest of the Lebanon', as well as the daily expenses of his invitations. ${ }^{38}$

According to Villalpando, the palace consisted of three parts: the house of the King, the house of the Queen and the House of the Forest of the Lebanon..$^{39}$ It has a rectangular structure with its façade towards the east, having two inner courtyards next to a large central hall. The corners of the building had towerlike shapes, slightly protruding outwardly. The façade had a central projection, crowned by a tower. Its exterior was made out of beautifully hewn blocks of stone, all perfectly rectangular. A double entablature divided the façade in three orders. The central element in the palace was the House of the Forest of the Lebanon, where the people could gather to hear Solomon speaking justice. Flavius Josephus had called this part a Basilica, in which all people could hear justice. Behind the Basilica was a porch, which was translated by Villalpando into a separate Courtroom with Solomon's throne. This combined element was placed centrally in the building and was visualised by a ground plan in Villalpando's book, measuring 100 by 50 by 30 for the House of the Forest of the Lebanon and 50 by 30 for the Courtroom. He elaborates on the Palace by saying that Vitruvius based his Basilica on the House of the Forest of the Lebanon. Both had a ground plan with a proportion of 1:2. Both structures needed to have galleries, which were one third of the width of the House of the Forest of the Lebanon. Villalpando explained how the architecture of the Palace equalled that of the Temple. Solomon had grasped the divine wisdom of the Temple architecture and used this knowledge to design his own palace. For the exterior, the architecture of the Temple was applied.

Many of these elements of Solomon's Palace were taken over by Van Campen. One cannot speak of a copy of the building; Van Campen transformed the basic idea of Solomon's Palace into the new town hall. In order to achieve this, he copied the main elements of Solomon's Palace. The most important element of Solomon's Palace was the House of the Forest of the Lebanon. It formed the heart of the Palace and was followed by Solomon's Courtroom. This disposition was taken over literally in the Amsterdam town hall. The same goes for the measurements of the Citizens' Hall. This was modelled after the House of the Forest of the Lebanon, which - according to Villalpando equalled the Basilica described by Vitruvius, which measured 60 by 120 feet.

38 Translation by: Morrison, Ezechielem explanationes 205, caput x.

39 Villalpando Juan Bautista, In Ezechielem explanationes et apparatus urbis ac templi Hiersolymitani, 3 vols. (Rome, Luigi Zannetti - Alfonso Ciaccone: 1596-1605), vol. II, cap. X-XII; and vol. III, 201-203. 
Another important proportion was 3:5, which Van Campen used for Citizens' Hall with the galleries, measuring in total 200 by 120 feet. ${ }^{40}$ Most importantly, the modular system for the town hall was taken over from Solomon's Palace. The ratio between the width of the exterior pilasters (columns) and the space in between them was 1:3; the ratio of width and height of the pilasters was 1:10, with cornice 1:12. Like all architecture by Solomon, the town hall was supposed to be executed in the Corinthian order.

Jacob van Campen had grasped the idea behind its building and especially the 'symmetria', the system proportions based on a module, a fixed measurement that determined all parts of the building. The width of the pilasters in relation to the intercolumnium and the height of the pilasters were taken over from Solomon's Palace. With a module of three feet, an intercolumnium of twelve feet and floors high 36 feet $(3 \times 12)$ the building referred to all kinds of perfect numbers related to Christianity and the proportions, prescribed by Villalpando. By recreating Solomon's Palace as a town hall in Amsterdam, Van Campen reflected the concept of the Dutch Republic as a New Israel. The burgomasters, who had strived for peace, were the kings of this town hall. Because of its function as a courthouse, Van Campen took Solomon's Palace as example. Of course, the situation in Amsterdam was different than that in Jerusalem. The town hall needed to function as such and in order to do so, Van Campen had to make some changes, but these changes were authorised by important writers about architecture. For instance, the Citizens' Hall was situated on the first floor, whereas the House of the Forest of the Lebanon and the Basilica were placed on the ground floor. The idea of lifting this hall a floor up came from Andrea Palladio's book I Quattro Libri dell'Architettura and exactly from those passages that Brosterhuijsen had translated on Van Campen's advice. Palladio described the old Basilica as a building with porticos, being one third of the width of the hall. Palladio situated the modern Basilica as a building situated on the first floor, while its portico's could be left out or applied at the outside of the building, or to be used as independent spaces. The Amsterdam town hall with independent galleries was the consequence of Palladio's ideas. Van Campen stayed in the classical context, using the permitted freedom to alter some aspects of a building without changing its essence.

40 Schmidt Johan Jacob, Bybelsche Mathematicus of Schriftuurlijke wiskundige; behelzende eene opheldering der Heilige Schrift, uit de wiskundige wetenschappen. Te weten: de rekenkunde, meetkunde, weegkunde, bouwkunde, starrekunde, uurwyzerkunde en gezichtkunde (Amsterdam - Dordrecht, Jacobus Loveringh and Abraham Bluss: 1768) 442. 
An important building like the town hall needed to have an interior decoration that matched the architecture of the building. The iconographical program consisted of sculpture and painting. Several sculptors and particularly Artus Quellinus (1609-1668) worked on an elaborate program of sculpture in the Citizens' Hall and the galleries. The sculpted decoration had a strong cosmic element. The galleries were adorned with statues of the planets, while the sculpted reliefs of the Citizens' Hall symbolized the four elements and the four parts of the world. The floor and ceiling were to get maps of the world as well as star maps. The offices and courtrooms were embellished with sculpture and paintings of 'exempla' taken from biblical and classical history. Solomon played a prominent part as main symbol for wisdom in the decoration of the Criminal Court, the most important space in the town hall, where death sentences were pronounced [Fig. 17.11]. The Judgement of Solomon is situated in the middle, flanked by Roman and Greek examples (Lucius Junius Brutus and Zaleucus). 'Solomon praying for wisdom', an enormous painting by Govert Flinck, was hung in the City Council. Interesting is also the personification of Amsterdam, situated in the top of the front tympanum at Dam Square [Fig. 17.12]. Amsterdam is visualised as a woman, wearing an imperial crown and sitting on a Lion's Throne, very similar to Solomon's throne as sculpted in the relief in the Criminal Court.

The sculpted works were published in prints, made by Hubertus Quellinus, the brother of Artus. The introduction to the second volume (1663) is addressed to the burgomasters. It tells the story of Solomon building the Temple and his own palace, and of the queen of Sheba, visiting Solomon's Palace and exclaiming that his wisdom and his works were even bigger than she had heard. Quellinus continued by stating that if people from other countries would come to see the town hall in Amsterdam, they would be sad, that their eyes could not be satisfied, 'openly acknowledging that the wisdom and the magnanimity of the Honourable Burgomasters are bigger than the rumour they had heard'.41 It

41 'Maar als zy [bezoekers uit andere landen] komen aan het Huys van U Ed. Achtbaerheden, en't selve soo uytwendigh als inwendigh door-siende, bevinden in soo veele groote Kamers verdeelt, met soo veele niet min kostelijcke als konstige Marmore Beelden verçiert, en hebben zy-lieden met de Coninginne Saba by nae geenen geest meer, en het is hen-lieden een verdriet, dat hunne oogen met sien niet en konnen verzaadt worden, opentlijk bekennende dat de wijsheyt en grootdadigheyt van V Ed. Achbaerheden grooter zijn als het gerucht dat zylieden gehoort hadden'. Quellinus Hubertus, Secunda pars praecipuarum effigierum ac ornamentorum amplissimae Curiae Amstelrodamensis maiori ex parte in $c a<n>$ dido marmore effectorum per Artum Quellinium [sic] eiusdem civitatis statuarium. 


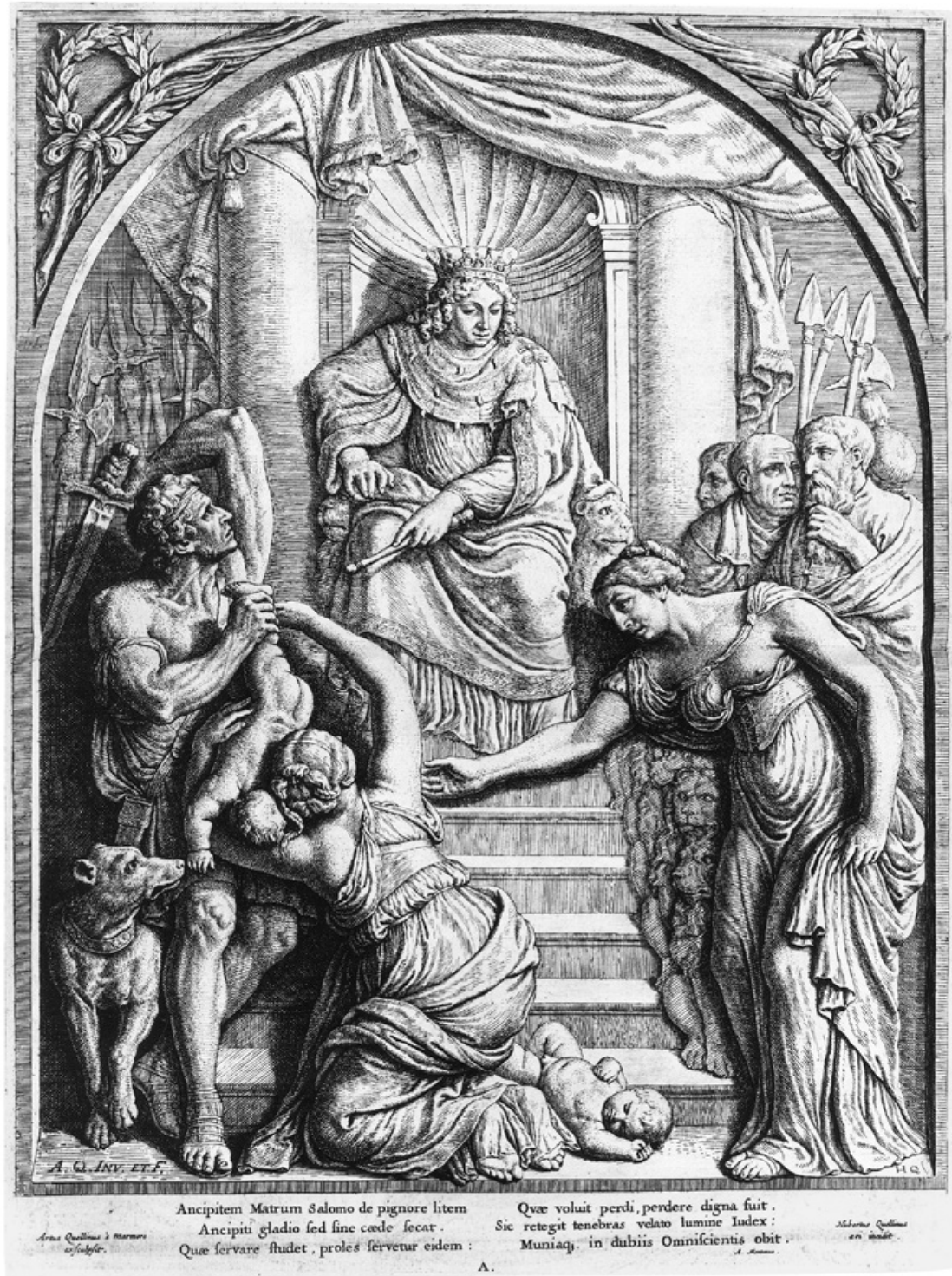

FIGURE 17.11 Hubertus Quellinus after Artus Quellinus, The Judgment of Solomon (1655). From: Quellinus Hubertus, Prima pars praecipuarum effigierum ac ornamentorum amplissimae Curiae Amstelrodamensis maiori ex parte in candido marmore effectorum per Artum Quellinium [sic] eiusdem civitatis statuarium. Het Eerste Deel. Van de voornaemste Statuen ende Ciraten, vant konstrijck Stadthuys van Amstelredam, tmeeste in marmer gemaeckt, door Artus Quellinus, Beelthouwer der voorseyde Stadt. La Premier Partie. De plusieurs Figures et ornements, de la Maison de Ville d'Amsterdam, le plus grand part faict d'marbre d'Artus Quellinus, Sculpteur de la ditte Ville (Amsterdam, Artus Quellinus: 1655). IMAGE (C) UTRECHT UNIVERSITY LIBRARY 


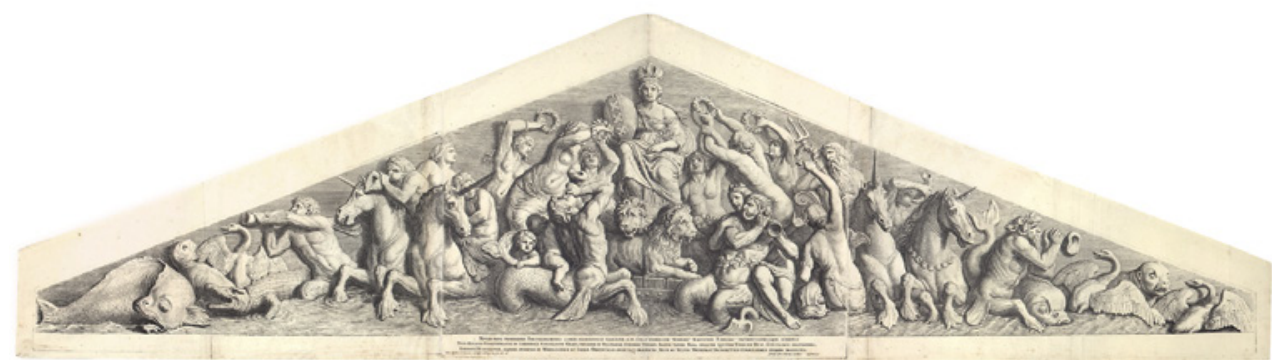

FIGURE 17.12 Hubertus Quellinus after Artus Quellinus, The Amsterdam town hall, the sculpted tympanon at the side of Damsquare with the Personification of Amsterdam on a throne of lions. From: Quellinus Hubertus, Secunda Pars praecipuarum effigierum ac ornamentorum amplissimae Curiae Amstelrodamensis maiori ex parte in ca $<n>$ dido marmore effectorum per Artum Quellinium [sic] eiusdem civitatis statuarium. Het Tweede Deel van de voornaemste Statuen ende Cieraten van't konst-rijcke Stadt-huys van Amstelredam 'tmeeste in Marmer gemaeckt door Artus Quellinus Beelthouwer der voorseyde Stadt (Amsterdam, Artus Quellinus: 1663). IMAGE (C) UTRECHT UNIVERSITY LIBRARY

seems hardly coincidental that Hubertus Quellinus, who stood in close contact to people with a prominent role in the execution of the building, uses Solomon and his palace as an example.

\section{$8 \quad$ Context and Conclusion}

The Amsterdam town hall was an emanation of Solomon's Palace. Van Campen took the general layout of the palace as example and adapted it to the Amsterdam situation. The burgomasters got a town hall befitting the new status of the city that celebrated the Westphalian Peace of 1648. The city and its four burgomasters were important participants on Europe's political stage of the seventeenth century. As new Solomons they brought peace and wealth to the city, which they almost ruled as an independent city state. This mirror image of a new Solomon was quite common: European kings identified themselves with Solomon as well. King James I (1566-1625) saw himself as God's

Het Tweede Deel van de voornaemste Statuen ende Cieraten van't konst-rijcke Stadt-huys van Amstelredam 'tmeeste in Marmer gemaeckt door Artus Quellinus Beelthouwer der voorseyde Stadt (Amsterdam, Artus Quellinus: 1663) dedicatory introduction. The title page has erroneously 'cadido' (read: 'candido'). 
viceroy in Britain and as 'a spiritual descendant of the Hebrew kings. ${ }^{42}$ When James was buried, bishop John Williams gave a sermon entitled 'Great Britain's Salomon'.43 As a new Solomon James had used his wisdom to bring prosperity and peace to the country. Especially peace was important to him - his motto was 'Beati Pacifici' - making the link to Solomon even more obvious. James' successor Charles I (1600-1649) commissioned Peter Paul Rubens to paint the ceiling of the Banqueting House. The ceiling was titled the 'Apotheosis of James I' and in one of the paintings James is depicted as the wise king Solomon (1629). Seen in this light, it cannot come as a surprise that Charles envisaged the enlargement of Whitehall Palace into a building based on the design of the Temple of Jerusalem by Villalpando. ${ }^{44}$ Ideas for such a palace must have derived from the Escorial in Spain, which Charles visited in 1623. The Escorial is the archetype of a royal palace based on the Temple, built by Philips II of Spain (1527-1598), who saw himself as 'alter Solomon' as well. ${ }^{45}$ The Escorial is a combination of a church, a monastery and a royal palace. The focal point is the church, taking over the place of the Holy of Holies in the Temple. The courtyards around it reflect the courts of the Temple. On the corners of the courtyards, towers arise, similar to the Temple. ${ }^{46}$ In France Louis XIV (16381715) had plans to enlarge the Louvre, using the Temple as example. His architect, François Mansart, owned a copy of Villalpando's book as well. ${ }^{47}$ All of these kings may have referred to Solomon's Temple, as they advocated the divine origin of monarchical rule.

Van Campen's choice for Solomon's Palace is rather unique within this context of architecture of rulers. It can only be explained by the fact that the function of a town hall was closer to Solomon's Palace than to the Temple. The

42 Parry G., The Golden Age restor'd. The culture of the Stuart Court, 1603-1642 (Manchester: 1981) 21, 22, 23, 26-29, 31-32, and 35. Quote taken from p. 23.

43 Parry, Golden Age 31. This sermon was published as: Williams John, Great Britains Salomon (London, Iohn Bill: 1625).

44 Wittkower R., "Federico Zuccari and John Wood of Bath", Journal of the Warburg and Courtauld Institutes 6 (1943) 220-222; Gunther R.T., The Architecture of Sir Roger Pratt (Oxford: 1928) 286, 304.

45 Bold J., John Webb. Architectural Theory and Practice in the Seventeenth Century (Oxford 1989) 107-125. For the Solomonic context of the Escorial, see Taylor R., "Architecture and Magic: Considerations on the Idea of the Escorial", in Fraser D. - Hibbard H. - Lewine M.J. (eds.), Essays in the History of Architecture presented to Rudolf Wittkower (London: 1967) 81-109.

46 See also Philibert de l'Orme's design for the Tuileries for Catherine de Medici. See Blunt A., Philibert de l'Orme (London: 1958).

47 Marías F., "La arquitectura de Felipe II: de las ciencias matemáticas al saber bíblico", in Felipe II y las artes (Madrid: 2000) 221-230; Braham A. - Smith P., François Mansart, 2 vols. (London: 1973). 
palace was most of all famous for its courtroom, in which the wise and peaceloving king Solomon administered justice. As such, it was a perfect example for a Dutch town hall, which mainly served as a courthouse. Van Campen gave the burgomasters what they wanted: a town hall in which justice was administered in a wealthy city where peace ruled under the reign of new Solomons, that brought peace to their city.

The Solomonic connotation had another advantage. The city and the architect found the appropriate history not within their own history - as other Dutch cities did - but in a far more ancient history. The architect found an example in the widely spread idea amongst the Dutch that they were the newly chosen people as Israel had been before. The appropriation of Solomon's Palace as example for the Amsterdam town hall connected the city with a history that was more than 2500 years old. Following the idea of Villalpando, biblical antiquity included all following Greek and Roman antiquity, which made it possible for Van Campen to use these cultures as well in the interior decoration of the building. Amsterdam set itself apart from other Dutch cities; it belonged to an international category of historical cities and leaders. To underline this, Van Campen created a palace for the burgomasters, in which they could act on the level of kings and receive people of high rank and noble birth.

\section{Select Bibliography}

Barlaeus Caspar, Blyde inkomst der allerdoorluchtighste koninginne, Maria de Medicis, t'Amsterdam (Amsterdam, Johan and Cornelis Blaeu: 1639).

Goudeau J., "Ezekiel for Solomon. The Temple of Jerusalem in Seventeenth-century Leiden and the Case of Cocceius", in Goudeau J. - Verhoeven M. - Weijers W. (eds.), The Imagined and Real Jerusalem in Art and Architecture (Leiden - Boston: 2014) 88-113.

Morrison T., Juan Bautista Villalpando's Ezechielem Explanationes. A Sixteenth-Century Architectural Text (Lewiston - Queenston - Lampeter: 2009).

Schama S., The Embarrassment of Riches. An Interpretation of Dutch Culture in the Golden Age (London: 1991 [1987 1 ).

Villalpando Juan Bautista, In Ezechielem Explanationes et Apparatus Urbis ac Templi Hiersolymitani, 3 vols. (Rome: Luigi Zannetti - Alfonso Ciaccone: 1596-1605).

Vlaardingerbroek P., Het paleis van de Republiek. Geschiedenis van het stadhuis van Amsterdam (Zwolle: 2011).

Vlaardingerbroek P., "The Snoge: A Jewish building in a Dutch architectural style", in Vlaardingerbroek P. (ed.), The Portuguese Synagogue in Amsterdam (Zwolle: 2013) $55^{-72 .}$ 